\title{
Drug pipeline: Q212
}

\section{Laura DeFrancesco}

In the first two quarters of 2012, there have been 12 approvals (NME and biologics) compared with 30 for 2011. The appovals of two obesity drugs, Qsymia and Belviq, a plant produced replacement enzyme for Gaucher's disease, Elelyso, and a PET imaging

\begin{tabular}{|c|c|c|}
\hline \multicolumn{3}{|c|}{ Notable regulatory approvals (Q2 2012) } \\
\hline Drug/company & Indication & Approval and drug information \\
\hline $\begin{array}{l}\text { Amyvid (florbetapir } \\
\text { F-18)/Eli Lilly }\end{array}$ & $\begin{array}{l}\text { Alzheimer's } \\
\text { imaging disease }\end{array}$ & $\begin{array}{l}4 / 6 / 12 \text {, FDA. } 18 \mathrm{~F} \text {-labeled small molecule allows detec- } \\
\text { tion of amyloid beta in patients through positron } \\
\text { emission tomography }\end{array}$ \\
\hline SOM230/Novartis & $\begin{array}{l}\text { Cushing's } \\
\text { syndrome }\end{array}$ & $\begin{array}{l}\text { 4/25/12, Europe. Cyclohexapeptide somatostatin analog } \\
\text { with unique ability to bind somatostatin receptor subtypes } \\
1-5\end{array}$ \\
\hline $\begin{array}{l}\text { Stendra (avanafil)/ } \\
\text { Vivus }\end{array}$ & $\begin{array}{l}\text { Erectile } \\
\text { dysfunction }\end{array}$ & $\begin{array}{l}\text { 4/12/12, FDA. Phosphodiesterase } 5 \text { inhibitor with faster } \\
\text { onset than marketed drugs }\end{array}$ \\
\hline $\begin{array}{l}\text { Elelyso (taliglucerase- } \\
\text { alpha)/Pfizer }\end{array}$ & $\begin{array}{l}\text { Gaucher's } \\
\text { disease }\end{array}$ & $\begin{array}{l}\text { 5/1/12. Human glucocerebrosidase expressed in carrot } \\
\text { cell line }\end{array}$ \\
\hline $\begin{array}{l}\text { Perjeta (pertuzumab)/ } \\
\text { Roche }\end{array}$ & Breast cancer & $\begin{array}{l}\text { 6/8/12, FDA. Humanized } m A b \text { that inhibits HER2 } \\
\text { dimerization by binding different epitope from Herceptin }\end{array}$ \\
\hline $\begin{array}{l}\text { Belviq (lorcaserin } \\
\text { hydrochloride)/Arena } \\
\text { Pharmaceuticals }\end{array}$ & Obesity & $\begin{array}{l}6 / 27 / 12 \text {, FDA. Small-molecule selective agonist of only } \\
5 \text {-hydroxy tryptamine } 2 \mathrm{C} \text { receptor subtype }\end{array}$ \\
\hline $\begin{array}{l}\text { Myrbetriq } \\
\text { (mirabegron)/ } \\
\text { Astellas Pharma }\end{array}$ & $\begin{array}{l}\text { Overactive } \\
\text { bladder }\end{array}$ & $\begin{array}{l}6 / 28 / 12 \text {, FDA. Small-molecule beta } 3 \text { adrenergic agonist, } \\
\text { relaxing smooth muscle }\end{array}$ \\
\hline $\begin{array}{l}\text { Qsymia (phentermine } \\
\text { and topiramate)/Vivus }\end{array}$ & Obesity & $\begin{array}{l}\text { 7/12/12, FDA. Amphetamine appetite suppressor and } \\
\text { anticonvulsant with unknown mechanism in obesity }\end{array}$ \\
\hline
\end{tabular}

\begin{tabular}{|c|c|c|}
\hline \multicolumn{3}{|c|}{ Notable regulatory setbacks (Q2 2012) } \\
\hline Drug/company & Indication & Setback summary \\
\hline $\begin{array}{l}\text { Setipiprant/ } \\
\text { Actelion }\end{array}$ & Allergic rhinitis & $\begin{array}{l}\text { 4/2/12. Phase } 3 \text { study of small-molecule antagonist of } \\
\text { chemoattractant receptor-homologous molecule expressed } \\
\text { on TH2 cells (CRTH2) failed to show efficacy }\end{array}$ \\
\hline $\begin{array}{l}\text { Vyndaqel (tafamidis } \\
\text { meglumine)/Pfizer }\end{array}$ & $\begin{array}{l}\text { Familial amyloid } \\
\text { polyneuropathy }\end{array}$ & $\begin{array}{l}\text { 6/18/12. FDA issued a complete response letter requesting } \\
\text { more efficacy data, despite EMA approval. Small molecule, } \\
\text { originally developed by FoldRx, stabilizes transthyretin, } \\
\text { inhibiting fibril formation }\end{array}$ \\
\hline $\begin{array}{l}\text { BMS-986094/ } \\
\text { Bristol-Myers } \\
\text { Squibb }\end{array}$ & Hepatitis C & $\begin{array}{l}8 / 1 / 10 \text {. Phase } 2 \mathrm{~b} \text { trial of nucleoside inhibitor of } \\
\text { RNA-dependent RNA polymerase (NS5b), originally } \\
\text { developed by Inhibitex, halted due to safety issues }\end{array}$ \\
\hline $\begin{array}{l}\text { Bapineuzumab/ } \\
\text { Pfizer and Johnson } \\
\text { \& Johnson }\end{array}$ & $\begin{array}{l}\text { Alzheimer's } \\
\text { disease }\end{array}$ & $\begin{array}{l}\text { 8/6/12. Phase } 3 \text { trial of anti-beta amyloid humanized mAb } \\
\text { discontinued after failing to meet co-primary endpoints }\end{array}$ \\
\hline $\begin{array}{l}\text { Talactoferin/ } \\
\text { Agennix }\end{array}$ & $\begin{array}{l}\text { Non-small cell } \\
\text { lung cancer }\end{array}$ & $\begin{array}{l}8 / 6 / 12 \text {. Phase } 3 \text { trial of dendritic cell activator (recombi- } \\
\text { nant human lactoferrin) suspended when overall survival of } \\
\text { patients did not improve }\end{array}$ \\
\hline $\begin{array}{l}\text { Cytofab } \\
\text { (AZD9773)/ } \\
\text { AstraZeneca }\end{array}$ & Sepsis & $\begin{array}{l}\text { 8/8/12. Company halted further development on this sheep } \\
\text { polyclonal anti-TNF alpha antibody after phase } 2 \mathrm{~b} \text { failed to } \\
\text { show improvement over placebo }\end{array}$ \\
\hline $\begin{array}{l}\text { Ganitumab (AMG } \\
\text { 479)/Amgen }\end{array}$ & $\begin{array}{l}\text { Pancreatic } \\
\text { cancer }\end{array}$ & $\begin{array}{l}\text { 8/8/12. Company halted phase } 3 \text { trial when human mAb } \\
\text { against insulin-like growth factor- } 1 \text { was unlikely to meet } \\
\text { overall survival endpoint }\end{array}$ \\
\hline
\end{tabular}

Source: BioMedTracker, a service of Sagient Research (http://www.biomedtracker.com/). FDA, US Food and Drug Administration; EMA, European Medicines Agency.

\begin{tabular}{|c|c|c|}
\hline Drug/company & Indication & Upcoming catalyst \\
\hline $\begin{array}{l}\text { Glybera (alipogene } \\
\text { tiparvovec/UniQure }\end{array}$ & $\begin{array}{l}\text { Lipoprotein } \\
\text { lipase deficiency }\end{array}$ & $\begin{array}{l}\text { 9/25/12, EMA. Glybera, a Ser } 447 X \text { variant of human } \\
\text { lipoprotein lipase gene delivered by AAV vector }\end{array}$ \\
\hline Linaclotide/Ironwood & $\begin{array}{l}\text { Irritable bowl } \\
\text { syndrome }\end{array}$ & $\begin{array}{l}\text { 9/8/12, PDUFA. Linaclotide, a } 14-\text { mer peptide } \\
\text { agonist of guanylate cyclase-C that increases fluid } \\
\text { secretion into the intestine }\end{array}$ \\
\hline Metreleptin/Amylin & Lipodystrophy & $\begin{array}{l}\text { 10/3/12, PDUFA. Metreleptin is recombinant human } \\
\text { leptin, which affects blood glucose and triglycerides }\end{array}$ \\
\hline Jetrea/Thr & $\begin{array}{l}\text { Vitreomacular } \\
\text { adhesion }\end{array}$ & $\begin{array}{l}10 / 17 / 12 \text {, PDUFA. Jetrea is recombinant microplas- } \\
\text { min, a truncated stable form of plasmin }\end{array}$ \\
\hline Enzalutamide/Astellas & Prostate cancer & $\begin{array}{l}11 / 21 / 12 \text {, PDUFA. Enzalutamide, an androgen recep- } \\
\text { tor antagonist of higher affinity than bicalutamide }\end{array}$ \\
\hline b/Exelixis & Thyro & $\begin{array}{l}11 / 29 / 12 \text {, PDUFA. Cabozantinib inhibits hepatocyte } \\
\text { growth factor receptor MET, RET and vascular endo- } \\
\text { thelial growth factor receptor } 2\end{array}$ \\
\hline $\begin{array}{l}\text { Raxibacumab (ABthrax)/ } \\
\text { Human Genome Sciences }\end{array}$ & Anthrax & $\begin{array}{l}12 / 15 / 12 \text {, PDUFA. Abthrax, a human monoclonal anti- } \\
\text { body that blocks anthrax from binding to cell surface }\end{array}$ \\
\hline $\begin{array}{l}\text { BG-12 (dimethyl } \\
\text { fumarate)/Biogen Idec }\end{array}$ & Multiple sclerosis & $\begin{array}{l}12 / 28 / 12 \text {, PDUFA. BG-12, a second-generation } \\
\text { fumarate that is immunomodulatory }\end{array}$ \\
\hline $\begin{array}{l}\text { Kynamro (mipomersen } \\
\text { sodium)/Sanofi }\end{array}$ & $\begin{array}{l}\text { Dyslipidemia/ } \\
\text { hypercholester- } \\
\text { olemia }\end{array}$ & $\begin{array}{l}\text { 12/31/12, EU. Mipomersen, 2'-0-(2-methoxy) } \\
\text { ethyl-modified ribose antisense oligo against } \\
\text { apoB-100 }\end{array}$ \\
\hline
\end{tabular}

Food and Drug Administration; EMA, European Medicines Agency. agent for Alzheimer's, Amyvid, were of note. Sodium glucose transporter 2 inhibitors continue to impress in the clinic. But trials of Pfizer's flagship Alzheimer's therapy bapineuzumab were finally suspended.

\section{FDA approvals by lead indication area}



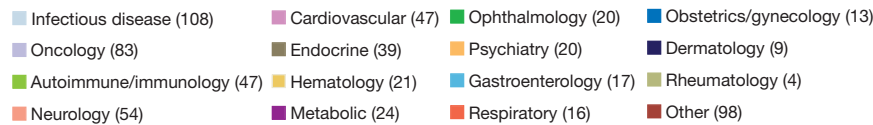

Source: FDA; BioMedTracker, a service of Sagient Research (http://www.biomedtracker.com/). *2012 partial year from Jan. 1 to Aug. 11 . Numbers in parentheses after legends are total approvals since 1995.

\begin{tabular}{|c|c|c|}
\hline \multicolumn{3}{|c|}{ Notable trial results (Q2 2012) } \\
\hline Drug/company & Indication & Results \\
\hline $\begin{array}{l}\text { Canagliflozin/Johnson } \\
\text { \& Johnson }\end{array}$ & Diabetes & $\begin{array}{l}\text { Phase } 3 \text { results of this sodium glucose transporter } 2 \\
\text { inhibitor improved glycemia in patients with moder- } \\
\text { ate renal impairment (Am. Diabetes Assoc., Abstract } \\
41 \mathrm{LB}, 2012 \text { ) }\end{array}$ \\
\hline $\begin{array}{l}\text { Dapagliflozin/Bristol- } \\
\text { Myers Squibb }\end{array}$ & Diabetes & $\begin{array}{l}\text { Phase } 3 \text { results of this sodium glucose transporter } 2 \\
\text { inhibitor demonstrated that } 10 \% \text { of TD2 patients with } \\
\text { cardiovascular disease achieved three endpoints (Am. } \\
\text { Diabetes Assoc., Abstract } 1114-\mathrm{P}, 2012 \text { ) }\end{array}$ \\
\hline Amatuximab/Esai & Mesothelioma & $\begin{array}{l}\text { Phase } 2 \text { results of chimeric mAb against mesothelin dem- } \\
\text { onstrated } 39 \% \text { with partial response, } 51 \% \text { with stable } \\
\text { disease with mean progression free survival of } 6.1 \text { months } \\
\text { (ASCO, Abstract } 7030,2012 \text { ) }\end{array}$ \\
\hline AMG386/Amgen & $\begin{array}{l}\text { Renal cell carci- } \\
\text { noma }\end{array}$ & $\begin{array}{l}\text { Phase } 2 \text { results of fusion protein (peptibody) targeting } \\
\text { angiopoietins demonstrated overall response rate of } \\
58-59 \% \text { (ASCO, Abstract } 4606,2012 \text { ) }\end{array}$ \\
\hline GLPG0634/Galapagos & $\begin{array}{l}\text { Rheumatoid } \\
\text { arthritis }\end{array}$ & $\begin{array}{l}\text { Phase } 2 \text { results of selective JAK1 inhbitor showed over- } \\
\text { all improvement in ACR2O in } 83 \% \text { of patients receiving } \\
\text { drug versus } 33 \% \text { receiving placebo (EUNETHYDIS Int. } \\
\text { Conf., Abstract OPO263, 2012) }\end{array}$ \\
\hline Ipragliflozin/Astellas & Diabetes & $\begin{array}{l}\text { Phase } 2 \text { trial of this sodium glucose transporter } 2 \text { inhibi- } \\
\text { tor shows that patients reduce A1C and body weight } \\
\text { (Am. Diabetes Assoc., Abstract 1046-P, 2012) }\end{array}$ \\
\hline Miravirsen/Santaris & Hepatitis C & $\begin{array}{l}\text { Phase } 2 \text { trial of oligonucleotide targeting MIR-122 } \\
\text { demonstrated prolonged dose dependent reduction in } \\
\text { HCV RNA (Eur. Assoc. Study Liver, Abstract } 58,2012 \text { ) }\end{array}$ \\
\hline PF-332991/Pfizer & Sarcoma & $\begin{array}{l}\text { Phase } 2 \text { results of cyclin dependent kinase } 4 / 6 \text { inhibi- } \\
\text { tor demonstrated } 70 \% \text { progression free survival at } \\
12 \text { weeks (ASCO, Abstract 10002, 2012). }\end{array}$ \\
\hline $\begin{array}{l}\text { Yttrium-90 clivatu- } \\
\text { zumab tetraxetan/ } \\
\text { Immunomedics }\end{array}$ & $\begin{array}{l}\text { Pancreatic } \\
\text { cancer }\end{array}$ & $\begin{array}{l}\text { Phase } 2 \text { trial of mAb targeting mucin antigen labeled } \\
\text { with yttrium- } 90 \text { demonstrated disease control in } 58 \% \\
\text { of patients in } 7.7 \text { months (Soc. Nucl. Med., Abstract } \\
495,2012 \text { ) }\end{array}$ \\
\hline
\end{tabular}

Source: BioMedTracker, a service of Sagient Research (http://www.biomedtracker.com/). FDA, US Food and Drug Administration; EMA, European Medicines Agency.

Corrected after print 7 December 2012.

Laura DeFrancesco is Senior Editor, Nature Biotechnology. 


\section{Erratum: My data are your data}

Vivien Marx

Nat. Biotechnol. 30, 509-511 (2012); doi:10.1038/nbt.2243; published online 7 June 2012; corrected after print 7 December 2012

In the version of this article initially published, the statement on p. 509, column 2, top paragraph, was missing a few words, making it a fragment: "Besides the risk of duplicating research discoveries that would be missed if data and methods aren't shared," should have read, "Besides the risk of duplicating research, 'it's also about discoveries and breakthroughs that would be entirely missed if data and methods aren't shared'..." On p. 511, column 2, paragraph 3, it was stated that the Lung Genomics Research Consortium (LGRC) shares data within the consortium but not with a wider community. In fact, that is not the case, and the sentence now reads, "Although the LGRC research portal is open, it does not offer sequence-based data, which must go to the NIH database of Genotypes and Phenotypes, where controlled data access policies are in place and individuals are de-identified." Also on p. 511, in column 3, paragraph 2, the European Systems Biology of Microorganisms program was incorrectly identified as SysMo-SEEK. It is SysMo. SysMO-Seek is a data-sharing platform developed for the 13 consortia that make up SysMo. The sentence now reads, "When developing a data-sharing platform called SysMO-SEEK for the European Systems Biology of Microorganisms program.... The errors have been corrected in the PDF and HTML versions of this article.

\section{Erratum: Beyond counting tumor cells}

Jim Kling

Nat. Biotechnol. 30, 578-580 (2012); doi:10.1038/nbt.2295; published online 9 July 2012; corrected after print 7 December 2012

In the version of this article originally published, On-Q-Ity platform was called by its previous and outdated name, C5 (Circulating Cancer and Characterization Chip). It should have been called OnQChip. The error has been corrected in the HMTL and PDF versions of the article.

\section{Erratum: Antibody specification beyond the target: claiming a later- generation therapeutic antibody by its target epitope}

Colin G Sandercock \& Ulrich Storz

Nat. Biotechnol. 30, 615-618 (2012); doi:10.1038/nbt.2291; published online 9 July 2012; corrected after print 7 December 2012

In the version of this article initially published, in Table 1 "Patents claiming anti-TNFa antibodies," patent US 7012135 should have been assigned to UCB Pharma and not UC Berkeley. The error has been corrected in the PDF and HTML versions of this article.

\section{Erratum: Drug pipeline: Q212}

\section{Laura DeFrancesco}

Nat. Biotechnol. 30, 817 (2012); doi:10.1038/nbt.2359; published online 10 September 2012; corrected after print 7 December 2012

In the version of this article initially published, the Thrombogenics drug Jetrea (recombinant microplasmin) was listed in "Notable upcoming regulatory decisions" as indicated for thyroid cancer. It should have read vitreomacular adhesion. The error has been corrected in the HMTL and PDF versions of the article.

\section{Corrigendum: Pharmacogenomics in clinical practice and drug development}

Andrew R Harper \& Eric J Topol

Nat. Biotechnol. 30, 1117-1124 (2012); doi:10.1038/nbt.2424; published online 8 November 2012; corrected after print 7 December 2012

In the version of this article initially published, the funders were not acknowledged. The funding statement should have read "E.J.T. was funded by the National Institutes of Health/National Center for Advancing Translational Sciences TR000109.” The error has been corrected in the HTML and PDF versions of the article. 